Vol. 1, No. 1, Oktober 2018

\title{
Layanan Bimbingan Kelompok dengan Teknik Sosiodrama dalam Pembentukan Karakter Toleransi
}

\author{
Mulyani, Mentari \\ 1) Dosen Bimbingan dan Konseling FKIP UPS Tegal \\ 2) Mahasiswa Bimbingan dan Konseling FKIP UPS Tegal
}

Program Studi Bimbingan dan Konseling

FKIP - Universitas Pancasakti Tegal

\begin{abstract}
Abstrak
Tujuan penelitian ini adalah Untuk mengetahui bagaimana tingkat pembentukan karakter toleransi sebelum diberikannya layanan bimbingan kelompok dengan teknik sosiodrama, mengetahui bagaimana tingkat pembentukan karakter toleransi sesudah diberikannya layanan bimbingan kelompok dengan teknik sosiodrama pada peserta didik. mengetahui apakah layanan bimbingan kelompok dengan teknik sosiodrama dapat digunakan dalam pembentuk karakter toleransi peserta didik. Populasi dalam penelitian ini adalah peserta didik jurusan Akutansi SMK Satya Praja 1 Petarukan, Pemalang Tahun Pelajaran 2014/2015. Jumlah elas XI akutansi tahun ajaran 2014/2015 berjumlah 192 peserta didik. peneliti mengunakan teknik cluster random sampling untuk pengambilan sampel berjumalah 28 siswa. Metode pengumpulan data menggunakan angket, wawancara, observasi dan dokumentasi. Teknik analisis data menggunakan analisis statistik deskriptif presentase dan analisis statistik uji t (t-test). Berdasarkan perhitungan hasil analisis data dengan statistik uji t dengan membandingkan hasil pre-test dengan hasil post-test untuk mengetahui tingkat karakter toleransi, dengan taraf signifikan 5\% maka diperoleh nilai thitung $>$ ttabel, yaitu 2,501 $>2,048$. Dengan demikian, dapat dinyatakan bahwa adanya hasil yang memuaskan mengenai penggunaan layanan bimbingan kelompok dengan teknik sosiodrama dalam pembentukan karakter toleransi.
\end{abstract}

Kata Kunci : Bimbingan Kelompok, Teknik Sosiodrama, Toleransi

\begin{abstract}
The purpose of this study was to determine how the level of tolerance of character formation before it provides the group with technical guidance services sociodramas, know how the level of tolerance after the formation of character it provides technical guidance services group with sociodramas learner. determine whether the group with technical guidance services sociodramas can be used in forming the character of tolerance learners. The population in this study is the students majoring in Accounting SMK Satya Praja 1 Petarukan Pemalang in the academic year 2014/2015. Total elas XI accounting academic year 2014/2015 amounted to 192 learners. Researchers using random cluster sampling technique for sampling berjumalah 28 students. Methods of data collection using questionnaires, interviews, observation and documentation. Data were analyzed using descriptive statistical analysis of the percentage and statistical analysis t test (t-test). Based on the calculation results of data analysis statistic test by comparing the pre-test to post-test results to determine the level of tolerance of character, with a significant level of $5 \%$, the obtained value of $t>t$ table, namely 2.501>2.048. Thus, it can be stated that the existence of satisfactory results regarding the use of group counseling services with sociodramas techniques in shaping the character of tolerance. with significance level of $5 \%$, the obtained value of $\mathrm{t}>\mathrm{t}$ table, namely $2.501>2.048$. Thus, it can be stated that the existence of satisfactory results regarding the use of group counseling services with sociodramas techniques in shaping the character of tolerance. with significance level of $5 \%$, the obtained value of $t>t$ table, namely $2.501>2.048$. Thus, it can be stated that the existence of satisfactory results regarding the use of group counseling services with sociodramas techniques in shaping the character of tolerance.

Keywords: Guidance Group, Engineering Sociodramas, Tolerance
\end{abstract}




\section{PENDAHULUAN}

Perkembangan teknologi berubah dengan cepat seakan-akan tanpa batasan. Semantara itu perkembangan teknologi sangat diperlukan guna meningkatkan sumber daya manusia yang komperhensif dan berkualitas sesuai dengan pelaksanaan pendidikan. Tujuan pendidikan nasional mempunyai makna bahwa potensi yang perlu dikembangkan dari siswa bukan hanya bukan dari aspek kognitif saja namun juga dari aspek afektif dan psikomotorik. Dengan kata lain pendidikan nasional juga bertujuan untuk membentuk karakter peserta didik. Menurut Koesoema (2011) karakter dianggap sama dengan kepribadian. Kepribadian dianggap sebagai ciri, karakter, gaya, sifat khas yang bersifat dari bentukanbentuan yang diterima dari lingkungan.

Pentingnya pendidikan karakter di sekolah secara intensif dengan keteladanan, kearifan, dan kebersamaan, baik dalam kegiatan intra kurikuler maupun ekstra kurikuler, sebagai sebuah pondasi kokoh yang bermanfaat bagi masa depan anak didik. Karakter yang dapat dikembangkan oleh peserta didik, yaitu : Religius, jujur, toleransi, disiplin, kerja keras, kreatif, mandiri, demokratis, rasa ingin tahu, semangat kebangsaan, cinta tanah air, menghargai prestasi, bersahabat atau komunikatif, cinta damai, gemar membaca, peduli lingkungan, peduli sosial, dan tanggungjawab.

Berdasarkan bahasan diatas karakteristik yang dapat dikembangkan peserta didik salah satunya adalah toleransi. Kata toleransi berasal dari bahasa latin tolerare yang berari bertahan atau memikul. Toleran disini diartikan dengan saling memikul walaupun pekerjaan itu tidak disukai; atau memberi tempat kepada orang lain. (Siagian, 1993:115).

Data empiris di lapangan banyak sekali peserta didik yang memiliki kesadaran yang rendah mengenai sifat toleransi. Bisa dilihat ketika mereka berbicara dan bertingkah laku kepada teman sebaya maupun kepada guru dan staf kepengurusan. Bahkan seringkali terdengar pembicaraan yang tidak pantas peserta didik katakan didepan guru mereka, contohnya mengenai masalah pribadi guru yang sering dijadikan barang ejekan atau gurauan. Dalam mengatasi masalah yang dialami peserta didik berkaitan dengan kesadaran rendah akan sifat toleransi yaitu menggunakan bimbingan kelompok dengan teknik sosiodrama.

Menurut Winkel dalam Hastuti (2004) Bimbingan kelompok merupakan salah satu layanan bimbingan dan konseling yang diberikan kepada sejumlah individu dalam bentuk kelompok dengan memanfaatkan dinamika kelompok. Bimbingan Kelompok adalah suatu layanan bimbingan yang diberikan kepada sejumlah peserta didik secara bersama-sama oleh seorang ahli (Guru Pembimbing/ Konselor) dengan menggunakan atau memanfaatkan dinamika kelompok. Dan berupa kegiatan bimbingan yang dilakukan secara berkelompok guna membantu individu dalam menyelesaikan, mengatur, maupun menyusun sebuah rencana atau kegiatan sesuai dengan kehidupan keseharian individu yang terarah, teratur dan kelompok dijadikan sebuah tempat berkeluh kesah, atau tempat berbagi dan bertukar pendapat. Bimbingan kelompok dengan teknik sosiodrama diharapkan dapat membuat peserta didik tidak merasa jenuh dan bosan.

Sosiodrama merupakan dramatisasi dari berbagai persoalan yang dapat timbul dalam pergaulan dengan oran-orang lain, termasuk konflik yang sering dialami dalam pergaulan sosial, Wingkel dalam Hastuti (2006) teknik dramatisasi yang digunakan untuk menunjukan kepada siswa tentang masalahmasalah yang biasa mereka jumpai dalam hubungan sosial atau pergaulan sehari-hari maupun hubungan antar manusia. Sejalan dengan hasil penelitian Alfian dkk (2013) Keefektifan Bimbingan Kelompok Dengan Teknik Sosiodrama Untuk Meningkatkan Keterampilan Interaksi Sosial Anggota Pengurus Osis menggunakan uji wilcoxon. Nilai yang lebih kecil adalah $R=R_{1}=21$. Untuk $n 1=n 2=6$. Dari tabel nilai $R$ diperoleh $\mathrm{R}_{0,05}=26$ dan $\mathrm{R}_{0,05}=23$. Pada tabel $\alpha=0,05$ diperoleh $\mathrm{R}=21<\mathrm{R}_{0,05}=26$. Maka $\mathrm{H}_{0}$ ditolak $\mathrm{H}_{\mathrm{a}}$ diterima.

Tujuan penelitian ini adalah Untuk mengetahui bagaimana tingkat pembentukan karakter toleransi sebelum diberikannya layanan bimbingan kelompok dengan teknik sosiodrama, mengetahui bagaimana tingkat pembentukan karakter toleransi sesudah diberikannya layanan bimbingan kelompok dengan teknik sosiodrama pada peserta didik. mengetahui apakah layanan bimbingan kelompok dengan teknik sosiodrama dapat digunakan dalam pembentuk karakter toleransi peserta didik. 


\section{METODE}

Pendekatan penelitian ini peneliti menggunakan penelitian kuantitatif. Menurut Suharsimi (2006) mengemukakan penelitian kuantitatif adalah pendekatan penelitian yang banyak dituntut mengunakan angka, mulai dari pengumpulan data, penafsiran terhadap data tersebut, serta penampilan hasilnya. Jenis penelitian yang digunakan yaitu penelitian eksperimen dimana penelitian ini dilakukan untuk mengetahui suatu layanan bimbingan kelompok dengan teknik problem sosiodrama terhadap subyek penelitian yaitu membentuk karakter toleransi peserta didik. penelitian ini, peneliti menggunakan pre-ekspermental design (eksperimen tidak sebenarnya) dengan menggunakan jenis pre-test and post-tes group design. Menurut Suharsimi (2010: 123-124) penelitian jenis ini dilakukan dua kali sebelum eksperimen dan sesudah eksperimen. Dengan demikian hasil perlakuan dapat diketahui lebih akurat, karena dapat membandingkan dengan keadaan sebelum diberi perlakuan.

Populasi dalam penelitian ini adalah peserta didik jurusan Akutansi SMK Satya Praja 1 Petarukan, Pemalang Tahun Pelajaran 2014/2015. Jumlah elas XI akutansi tahun ajaran 2014/2015 berjumlah 192 peserta didik. Sampel penelitian merupakan sebagian yang diambil dari populasi yang akan mewakili dari populasi yang ada. Dalam penelitian ini, peneliti mengunakan teknik cluster random sampling untuk pengambilan sampel. Dengan mengambil sampel, jurusan Akutansi yang terdiri dari lima. Dengan demikian julah sempel pada penelitian ini berjumlah 28 peserta didik. Teknik pengumpulan data pada penilitian ini menggunakan angket atau kuisioner, observasi, dokumentasi dan wawancara. Tenik analisis data dalam penlitian ini menggunakan deskriptif presentase dan analisis uji-t.

\section{HASIL}

Sebelum Instrumen digunakan dalam penelitian, perlu dilakukan uji coba (try-out) terlebih dahulu. Try out ini dilakukan kepada responden lain yang bukan sampel yang kemudian dihitung validitas dan reliabilitasnya. Penulis mengadakan uji coba instrumen pada 20 peserta didik jurusan Akutansi SMK Nusantara Comal Kabupaten Pemalang Tahun Pelajaran 2014/2015 pada tanggal 19 Mei 2015. Hasil penghitungan uji validitas bimbingan konseling dengan teknik sosiodrama $\mathrm{r}_{\text {hitung }}$ kemudian dikonsultasikan $\mathrm{r}_{\text {tabel }}$ dengan jumlah responden try out yaitu $\mathrm{N}=20$ dengan taraf signifikansi $5 \%$ didapatkan $\mathrm{r}_{\text {tabel }}$ sebesar 0,444 . nomor item $1,2,3,4,6,7,8,9,11,12,13,15,16,18$, dan 19 dinyatakan valid karena $r_{x y}>r_{\text {tabel }}$, sedangkan nomor item 5, 10,14, 17 dan 20 dinyatakan tidak valid karena $\mathrm{r}_{\mathrm{xy}}<\mathrm{r}_{\text {tabel. }}$. Perhitungan validitas angket pembentukan karakter toleransi Hasil penghitungan $r_{\text {hitung }}$ kemudian dikonsultasikan $r_{\text {tabel }}$ dengan jumlah responden try out yaitu $\mathrm{N}=20$ dengan taraf signifikansi $5 \%$ didapatkan $\mathrm{r}_{\text {tabel }}$ sebesar 0,444 . hasil uji validitas angket pembentukan karakter toleransi peserta didik jurusan Akutansi di atas, diperoleh bahwa nomor item 1, 2, 3, 4, 5, 6, 7, 8, 9, 10,11, 12, 13, 14, 16, 17, 19, 20, 21, 22, 24, 25, 27, 28, dan 30 dinyatakan valid karena $r_{\mathrm{xy}}>\mathrm{r}_{\text {tabel}}$, sedangkan nomor item 15, 18, 23, 26 dan 29 dinyatakan tidak valid karena $\mathrm{r}_{\mathrm{xy}}<\mathrm{r}_{\text {tabel, }}$ Uji reliabilitas angket layanan bimbingan kelopok teknik sosiodrama diperoleh nilai rhitung sebesar 0,761 kemudian dikonsultasikan dengan $\mathrm{r}_{\text {tabel }}$ dengan taraf signifikan $5 \%$ dengan $\mathrm{N}=20$ hasilnya diperoleh 0,444 . Dengan ini maka $r_{\text {hitung }}>$ padar $_{\text {tabel }}$ yaitu $0,761>0,444$ dengan demikian angket layanan bimbingan kelompok dengan teknik sosiodrama dinyatakan reliabel. Sedangkan uji reliabilitas angket pembentuan karakter diperoleh nilai $r_{\text {hitung }}$ sebesar 0,857 kemudian dikonsultasikan dengan $r_{\text {tabel }}$ dengan taraf signifikan 5\% dengan $N=20$ hasilnya diperoleh 0,444 . Dengan ini maka $r_{\text {hitung }}>$ pada $r_{\text {tabel }}$ yaitu 0,857 >0,444 dengan demikian angket pembentukan karakter toleransi dinyatakan reliabel.

Hasil presentase pretest akan disajikan dalam tabel dan grafik berikut :

Tabel 4.1

Persentase Pre-test

\begin{tabular}{c|c|c|c}
\hline Interval Nilai & Kriteria & Frekuensi & Persentase (\%) \\
\hline $55-61$ & Sangat Rendah & 3 & $10,71 \%$ \\
\hline $62-68$ & Rendah & 3 & $10,71 \%$ \\
\hline $69-75$ & Kurang & 13 & $46,42 \%$ \\
\hline $76-82$ & Cukup & 2 & $7,14 \%$ \\
\hline
\end{tabular}




\begin{tabular}{c|c|c|c}
$83-89$ & Tinggi & 5 & $17,85 \%)$ \\
\hline $90-96$ & Sangat Tinggi & 2 & $7,14 \%$ \\
\hline \multicolumn{2}{c|}{ Jumlah } & 28 & $99.97 \%$ \\
\hline
\end{tabular}

Berdasarkan tabel pre-test diatas dari 28 mahasiswa termasuk dalam kategori sangat rendah sebanyak 3 peserta didik (10.71\%), kategori rendah sebanyak 3 peserta didik (10,71\%), kategori kurang sebanyak 13 peserta didik (46,42\%), kategori cukup sebanyak 2 peserta didik $(7,14 \%)$, kategori tinggi 5 peserta didik $(17,85 \%)$ dan kategori sangat tinggi sebanyak 2 peserta didik $(7,14 \%)$.

4.1 Gambar

Karakter Toleransi Pre-test

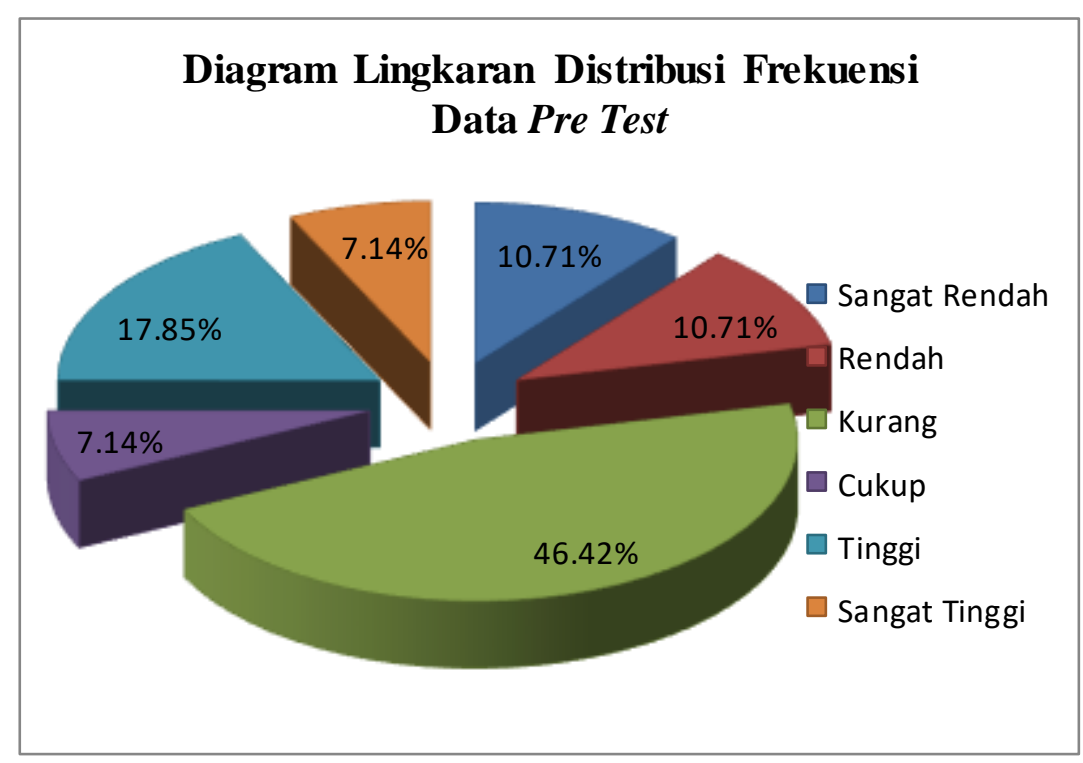

Sedangkan hasil post-test ditampilkan pada tabel berikut :

Tabel. 1 Post-test

\begin{tabular}{|c|c|c|c|}
\hline Interval Nilai & Kriteria & Frekuensi & Persentase (\%) \\
\hline $63-68$ & Sangat Rendah & 2 & $7,14 \%$ \\
\hline $69-74$ & Rendah & 3 & $10,71 \%$ \\
\hline $75-80$ & Kurang & 2 & $7,14 \%$ \\
\hline $81-86$ & Cukup & 8 & $28,57 \%$ \\
\hline $87-92$ & Tinggi & 10 & $35,71 \%$ \\
\hline $93-98$ & Sangat Tinggi & 3 & $10,71 \%$ \\
\hline \multicolumn{2}{|c|}{ Jumlah } & 28 & $99,98 \%$ \\
\hline
\end{tabular}

Berdasarkan tabel pre-test diatas dari 28 mahasiswa termasuk dalam kategori sangat rendah sebanyak 2 peserta didik $(7,141 \%)$, kategori rendah sebanyak 3 peserta didik $(10,71 \%)$, kategori kurang sebanyak 2 peserta didik (7,14\%), kategori cukup sebanyak 8 peserta didik (28,57\%), kategori tinggi 10 peserta didik $(35,71 \%)$ dan kategori sangat tinggi sebanyak 3 peserta didik (10,71\%). 
4.2 Gambar

Karakter Toleransi Pre-test

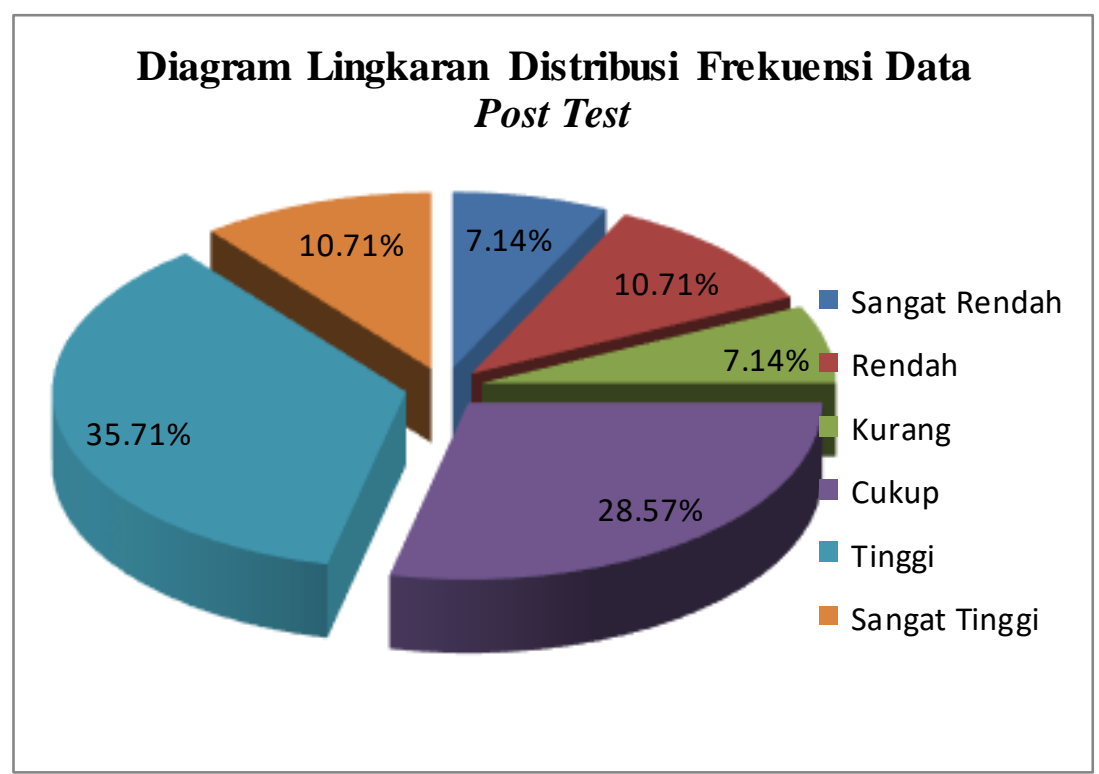

Dari proses penghitungan uji $\mathrm{t}$ diperoleh nilai $\mathrm{t}_{\text {hitung }}=2,501$ yang kemudian dikonsultasikan dengan nilai tabel pada taraf signifikan 5\% dan derajat kebebasan $(\mathrm{df})=\mathrm{n}-1=28-1=27$ maka $\mathrm{t}_{\text {tabel }}=2.048$ Dengan demikian $t_{\text {hitung }}>t_{\text {tabel }}$ yaitu 2,501 $>2.048$. hasil konsultasi di atas, diketahui bahwa $t_{\text {hitung }}>t_{\text {tabel }}$ maka dapat diketahui pula bahwa Ho ditolak sedangkan Hk diterima. Dapat disebutkan bahwa adanya pengaruh layanan bimbingan kelompok dengan teknik sosiodrama dalam pembentukan karakter toleransi peserta didik jurusan Akutansi SMK Satya Praja 1 Petarukan Kabupaten Pemalang.

Diagram batang perbandingan jumlah skor pre-test dengan post-test sebagai berikut:

Gambar 4.3 perbandingan pre-test dan post-test

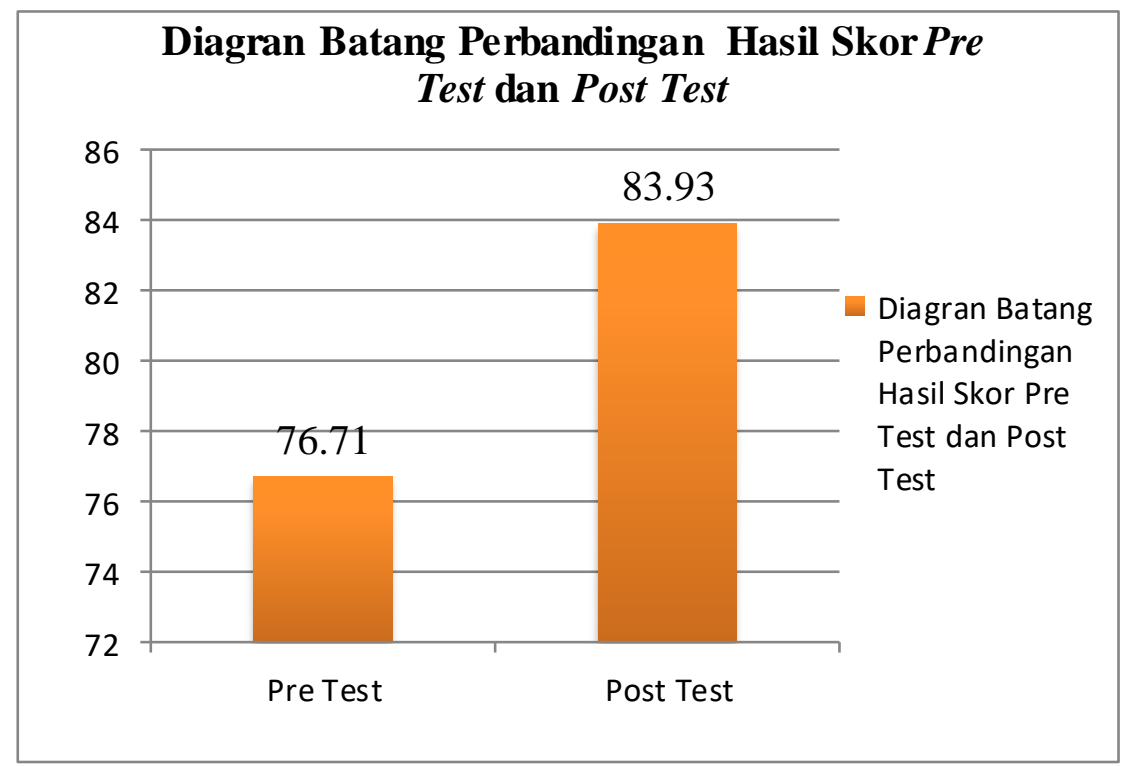


Hasil pre-test yang telah dianalisis dengan menggunakan deskriptif persentase, dari 28 peserta didik yang mengikuti layanan bimbingan kelompok dengan teknik sosiodrama terdapat 13 peserta didik yang memiliki karakter toleransi yang tergolong kurang dengan kisaran persentase $46,42 \%$. Sedangkan hasil post-test yang telah dianalisis dengan menggunakan deskriptif persentase, dari 28 peseta didik yang telah mengikuti layanan konseling behavior selama 3 kali pertemuan terdapat 10 peserta didik yang memiliki karakter toleransi yang tergolong tinggi dengan kisaran persentase $35,71 \%$. Berdasarkan perhitungan hasil analisis data dengan statistik uji t dengan membandingkan hasil pre-test dengan hasil post-test untuk mengetahui tingkat karakter toleransi, dengan taraf signifikan 5\% maka diperoleh nilai $t_{\text {hitung }}>t_{\text {tabel }}$, yaitu $2,501>2,048$. Dengan demikian, dapat dinyatakan bahwa adanya hasil yang memuaskan mengenai penggunaan layanan bimbingan kelompok dengan teknik sosiodrama dalam pembentukan karakter toleransi.

\section{SIMPULAN}

Penggunaan Layanan Bimbingan Kelompok dengan Teknik Sosiodrama dalam Pembentukan Karakter Toleransi Peserta Didik Jurusan Akutansi SMK Satya Paraja 1 Petarukan Kabupaten Pemalang Tahun Pelajaran 2014/2015 dapat disimpulkan : 1) tingkat pembentukan karakter toleransi sebelum dilaksanakan layanan tergolong dalam kriteria "kurang" yaitu 46,42\%, terbukti dari 28 peserta didik yang menjadi populasi penelitian diperoleh skor paling banyak pada interval nilai 69 - 75 sebanyak 13 peserta didik. 2) tingat pembentukan karakter toleransi sesudah dilaksanakan layanan tergolong dalam kriteria "tinggi" yaitu $35,71 \%$, terbukti dari 28 peserta didik yang menjadi populasi penelitian diperoleh skor paling banyak pada interval nilai 87 - 92 sebanyak 10 peserta didik.3) hasil analisis data dengan statistic uji t dengan membandingkan hasil pre-test dengan hasil post-test untuk mengetahui tingkat karakter toleransi, dengan taraf signifikan 5\% dengan drajat kebebasan (dk/df) sejumlah $\mathrm{N}-1=28-1=27$, maka diperoleh nilai $t_{\text {hitung }}>t_{\text {tabel }}$, yaitu 2,501 $>2,048$. Dengan demikian, dapat dinyatakan diterima.

\section{SARAN}

Berdasarkan hasil penelitian maka peneliti mengajukan saran seabagi berikut :1) disarankan bagi pihak sekolah agar dapat meningkatkan penggunaan layanan bimbingan kelompok yang dilaksanakan guru BK untuk membantu peserta didik yang mengalami permasalahan terutama tentang karakter toleransi peserta didik. 2) diharapkan peserta didik mampu mempertahankan karakter toleransi tersebut dan mengaplikasikanya dalam kehidupan sehari-hari baik di lingkungan sekolah maupun keseharian.3) disarankan bagi peserta didik hendaknya lebih memperhatikan lagi mengenai karakter yang meraka miliki.

\section{DAFTAR PUSTAKA}

Albertus, Doni Koesoema. 2011. Pendidikan Karakter. Jakarta: Grasindo.

Arikunto, Suharsimi. 2006. Metodologi Penelitian. Yogyakarta: Rineka Cipta

Arikunto, Suharsimi. 2010. Prosedure Penelitian Suatu Pendekatan Praktik. Jakarta: PT Rikena Cipta

\section{S. H. Siagian. 1993. Agama-agama Di Indonesia. Semarang: Satya Wacana}

Wingkel, W.S. dan M.M. Sri Hastuti. 2004. Bimbingan Dan Konseling Di Institusi Pendidikan. Yogyakarta: Media Abadi

Winkel, W.S. dan M.M. Sri Hastuti. 2006. Bimbingan dan Konseling Di Institusi Pendidikan. Yogyakarta: Media Abadi

Yanis, Alfian. Warsito, Hadi. Darminto, Eko. Lukitaningsih, Retno. 2013. Keefektifan Bimbingan Kelompok dengan Teknik Sosiodrama untuk Meningkatkan Keterampilan Interaksi Sosial Anggota Pengurus OSIS. Jurnal BK UNESA. Vol 1 edisi 2, 105-111. 